\title{
Multi-level governance for large marine commons: Politics and polycentricity in Palau's protected area network
}

\author{
Rebecca L. Gruby ${ }^{a, *}$, Xavier Basurto ${ }^{b}$ \\ ${ }^{a}$ Human Dimensions Of Natural Resources, Colorado State University, 1480 Campus Delivery, Fort Collins, \\ CO 80523-1480, United States \\ ${ }^{\mathrm{b}}$ Nicholas School of the Environment, Duke University, 135 Duke Marine Lab Road, Beaufort, NC 28516, United States
}

\section{A R T I C L E I N F O}

Article history:

Received 1 March 2013

Received in revised form

21 June 2013

Accepted 23 June 2013

Available online 22 July 2013

\section{Keywords:}

Common pool resources

Institutional analysis

Conservation governance

Scale

Human geography

Protected areas

Pacific Islands

\begin{abstract}
A B S T R A C T
This paper brings together institutional theories of polycentricity and critical human geography theory on scalar politics to advance understanding of the form and function of nested, polycentric regimes for the governance of large-scale common pool resources. We focus on institutional changes associated with a national marine protected area network in Palau through which national government and NGOs gain influence in local decisionmaking processes. Influence is gained through an attempt to scale up common-pool resource governance to an ecologically-relevant spatial scale in an effort to protect coral reef resilience and biodiversity across Palau. An institutional approach informed by scalar politics brings into focus potential tradeoffs between organizing governance reform around ecologically versus institutionally relevant scales. Our analysis suggests that prioritization of ecologically-relevant scales in institutional reform resulted in more nested but less polycentric institutional arrangements governing the network. We conclude that less distributed decision-making in the overall nested governance system could threaten the sustainability and resilience of coral reefs in the long-term by constraining institutional innovation and diversity. Results demonstrate the potential for interdisciplinary dialog to advance the research frontier on multi-level governance for large common pool resources.
\end{abstract}

(C) 2013 Elsevier Ltd. All rights reserved.

\section{Introduction}

Common pool resource (CPR) theory as defined by the Bloomington School (Aligica and Boettke, 2011) emerged mainly from research in local, small-scale settings (Ostrom, 1990). A critical research frontier is the governance of larger CPRs, which requires analysis of interdependencies among different levels and scales of more complex systems (Heikkila et al., 2011; Ostrom, 2009). We take Elinor Ostrom's design principle of polycentric, nested enterprises in long enduring, larger CPR systems as a starting point for interdisciplinary research on the governance of large CPRs (Marshall, 2008). Specifically, this paper brings together institutional theories of polycentricity and critical human geography theory on scalar politics to contribute to emerging research and policy agendas on the governance of larger CPRs by advancing understanding of the form and function of nested, polycentric regimes. We highlight complementarities between these theoretical approaches in agreement with Lejano (2006) that multiple analytical lenses can reveal different aspects of a policy situation.

A well-suited policy arena in which to explore these issues is marine conservation governance, particularly marine

\footnotetext{
* Corresponding author. Tel.: +1 9704915220.

E-mail addresses: Rebecca.Gruby@colostate.edu (R.L. Gruby), xavier.basurto@duke.edu (X. Basurto). 1462-9011/\$ - see front matter (C) 2013 Elsevier Ltd. All rights reserved. 
protected area MPA networks. Marine ecologists have concluded, "If marine reserves and other MPAs are to provide significant conservation benefits to species, they must be scaled up" (Gaines et al., 2010, p. 18286). As an alternative to scaling up the geographic extent of individual MPAs, conservationists are increasingly promoting large scale marine governance through networks of smaller MPAs that may spread the costs of conservation across resource owners and/ or users, and "can have emergent benefits that make the network more than the sum of its individual parts" (Gaines et al., 2010, p. 18286). The most prominent global policymaking fora (i.e., World Summit on Sustainable Development, the World Parks Congress, and the United Nations Convention on Biological Diversity) have all called for ecologically representative MPA networks (Gray, 2010).

In theory, an MPA network stretching across a large marine CPR is networked in both biophysical and social dimensions. As Agardy (2005, p. 244) has pointed out, an MPA network has "a dual nature" of "connecting physical sites deemed ecologically critical (ecological networks), and linking people and institutions in order to make effective conservation possible (human networks)." While there has been a proliferation of research on the biophysical dimensions of MPA networks (e.g., Airamé et al., 2003; Botsford et al., 2003; Gaines et al., 2010; Moffitt et al., 2011; Roberts et al., 2003), there has been comparatively little research on the political and institutional dimensions thereof (but see Grilo, 2011; Lowry et al., 2009; Sievanen et al., 2013). To be clear, institutions herein refer to the formal and informal rules, norms, and strategies that structure human interactions (Ostrom, 2005).

To address this gap and explore our theoretical interests in multi-level governance for larger CPRs, we focus on institutional changes and politics associated with a national protected area network (PAN hereafter) in the western Pacific Island nation of Palau, a context in which communities of resource users both own and manage marine resources. Through the PAN, national government and NGO actors are providing financial incentives to resource users/owners to voluntarily enroll pre-existing and new protected areas ${ }^{1}$ into a national network. Although resource users maintain ownership of PAN sites, there are significant changes to the process of governing those sites. As the PAN attempts to increase the spatial scale of marine governance to accommodate goals of biodiversity conservation, national government and conservation NGOs gain more influence in local decision-making processes. We conclude that the pursuit of large-scale marine conservation in Palau has led to a more nested but less polycentric governance system, and caution that decreased local autonomy may reduce the institutional diversity upon which the long-term sustainability of CPRs may depend. Results are broadly relevant as Palau's PAN is being promoted as a model for other nations seeking to meet their commitments to multilateral environmental agreements. ${ }^{2}$

\footnotetext{
${ }^{1}$ While the PAN includes terrestrial areas, our concentration on the marine component reflects the focus of the PAN and historic local conservation on marine environments.

2 Palau received the high profile 2012 Future Policy Award for having the world's best policies to protect oceans and coasts.
}

\section{Complementary perspectives on multi- level CPR governance}

According to Giordano (2003, p. 365), "the field of geography has been relatively silent in the commons literature, especially on the theoretic front." This is beginning to change. There is an emerging foundation of interdisciplinary theoretical dialog regarding the relationships between physical geography, resource users, and institutional arrangements for CPR governance (e.g., Araral, 2013a,b; Brewer, 2010; Giordano, 2003). However, there remains little constructive engagement between Bloomington School institutional theorists and critical human geographers interested in the scalar dimensions of CPR governance (hereafter, institutional theorists and critical human geographers) (Poteete, 2012), arguably due to divisive tensions about core questions, values, assumptions and methodologies (Johnson, 2004; Mosse, 1997).

While Johnson (2004) concludes that co-existence is more likely than convergence, ${ }^{3}$ there is emerging interest in a third option: complementarity (e.g., Armitage, 2008; Clement, 2010; Campbell, 2007; Poteete, 2012). Poteete (2012) for example, brings together concepts across multiple disciplines, including critical human geography and Bloomington institutional analysis, to argue for broader perspectives on the multi-level institutions and multiple scale linkages characterizing CPRs. Research taking a broader perspective, she argues, "is less likely to overlook important elements, relationships, or processes" (Poteete, 2012, p. 147). Armitage (2008, p. 7) similarly advocates for "critical reflection" on multi-level governance for CPRs, calling for the exchange of ideas from common property theory, resilience thinking, and political ecology.

In agreement that "continued cross-fertilization of ideas is crucial for the evolution of commons governance" (Armitage, 2008, p. 26), we explore complementarity between "Bloomington institutionalism" (Aligica and Boettke, 2011, p. 29), grounded in the seminal work of Vincent and Elinor Ostrom et al., and critical human geography theory on scalar politics. This section describes arguments and analytical foci within each literature, demonstrating that they share key concerns with power, scale, and multi-level governance. We argue that key components of the theoretical perspectives fit together to structure a more comprehensive analysis of multi-level governance regimes for larger CPRs, such as networks of marine protected areas.

\subsection{Polycentricity}

In 1961, influenced by the study of federalist systems, Ostrom et al. observed that some federalist systems were organized as polycentric political systems, arguing that they could constitute a potential alternative to the theoretical ideal of monocentric systems with a dominant center of decisionmaking power. The term polycentric "connotes many centers

\footnotetext{
${ }^{3}$ Johnson (2004) describes tensions between "collective action" and "entitlement" schools of thought that generally correspond to what we refer to here as institutionalist and critical human geography perspectives.
} 
of decision-making which are formally independent of each other" (Ostrom et al., 1961, p. 831). In polycentric political systems, multiple centers of decision-making "may function in a coherent manner with consistent and predictable patterns of interacting behavior" (Ostrom et al., 1961, p. 831). Throughout the 1990s and 2000s, an empirical research agenda on polycentricism focused on the role of local institutions for the governance of CPRs, although few studies have used polycentrism as a framework for analysis (Andersson and Ostrom, 2008; Araral, 2013a,b).

In its theoretical ideal, a polycentric system is thought to be more likely to enhance the ability of resource users to craft and adjust their own institutions over time, which can increase the likelihood of those institutions leading to effective, equitable, or sustainable outcomes because they are more likely to be well matched to particular social-ecological contexts (Andersson and Ostrom, 2008; Ostrom, 2012). Ostrom's eighth design principle holds that for CPRs that are part of larger systems, enduring polycentric governance is "organized in multiple layers of nested enterprises," where "smaller-scale organizations tend to be nested in ever larger organizations" (Ostrom, 2005, p. 269). Note, however, that a nested governance system in which decision-making power is not distributed among different actors does not constitute a polycentric system. A nested system where decision-making is centralized is less likely to succeed in supporting sustainability and resilience of the resources it governs. In theory, a nested polycentric system is advantageous because, through the involvement of resource users, local knowledge can inform the design of diverse, context-specific rules, while larger organizations (including but not limited to governments) can enhance local capacity to deal with non-contributors or local tyrants, share and invest in information, and coordinate crossboundary problems, for example (Ostrom, 2010; see also Mansbridge, 2013).

However, there is still limited understanding of the operational characteristics of such systems. Ostrom (2012, p. 140) concluded, "[o]ur own research supports more complex, adaptive designs that do enable the users to have a substantial voice in the design and monitoring of the rules in use but also involve larger units in a polycentric system." While a defining concept in polycentricity is the level of autonomy local participants have from larger units, there is little guidance on what constitutes a "substantial voice," how nesting affects the polycentricity of a given system, and how varying levels and forms of autonomy affect the function and overall trajectory of the system. Depending on the autonomy local units have, a given governance system may exhibit more or less polycentrism. More polycentric systems will show significant autonomy for decision-making among local units and units operating over larger jurisdictions. In less polycentric systems, for example, nested enterprises may engender partial or complete dominance of local groups by government regulators or other powerful actors (Adger et al., 2005; Marshall, 2008; Young, 2006).

\subsection{Scalar politics}

Critical human geographers, including political ecologists, are similarly interested in the relationships among actors, institutions, and spatial scale in multi-level CPR governance (often referred to as "multi-scaled" environmental governance in this literature). As part of this research agenda, critical human geographers are engaging a body of literature articulating as "politics of scale" or "scalar politics" (scalar politics herein) (MacKinnon, 2011, p. 22) to analyze the social construction and manipulation of spatial scales as part of "social strategies to combat and defend control over limited resources and/or a struggle for empowerment." (Swyngedouw and Heynen, p. 913). In this sense, social and biophysical scales are understood as dynamic, historically contingent tools of politics that actors wield as part of strategies to pursue particular agendas, such as gaining control over space, natural resources, and/or a governance process (Brown and Purcell, 2005; Gruby and Campbell, in press; McCarthy, 2005). While this literature advocates recognition of the biophysical and social processes that co-produce scales of social and ecological organization (Sneddon, 2003), there is increasing awareness that biophysical scales (i.e., watershed, ecosystem, eco-region) may also be identified and invoked in support of particular political projects, such as biodiversity conservation (Campbell, 2007; Campbell and Godfrey, 2010; Cohen, 2012; Sievanen et al., 2013).

Critical human geographers engage theory on scalar politics to critically assess social and biophysical scales and consider the role of scalar constructions and narratives in efforts to reconfigure and legitimize new forms of multi-level CPR governance (Sievanen et al., 2013). For example, Campbell (2007, p. 327) shows how sea turtle experts invoke spatial scales of sea turtle distribution and migration of sea turtles to "override local rights of withdrawal, management, and exclusion, and to assign these rights at other sociopolitical scales." Analytical attention thus focuses on "who produces scale, how, and for what purposes" (McCarthy, 2005, p. 733). This literature recognizes that rescaling environmental governance may result in significant social and ecological outcomes, but tends to focus on those associated with actor dis/empowerment (Norman and Bakker, 2009; Sievanen et al., 2013). While the literature contributes policy-relevant analysis, it generally does not engage with the institutional theory described in Section 2.1.

\subsection{Toward constructive dialog}

We take shared concerns with scale, power, and multi-level governance as a point of entry toward constructive dialog between institutional theorists and critical human geographers. We argue that complementary loci of attention advance a more complete, critical analysis of the form and function of large-scale CPR governance by directing analytical attention to the actors, agendas, and institutional changes associated with political projects to scale up and coordinate polycentric systems. The dual objectives of this study are thus to advance constructive theoretical dialog by exploring how new configurations of participants and institutions in nested regimes for larger CPRs affects the degree to which the system is polycentric. In the following sections we illustrate how this theoretical dialog can inform the analysis of dynamic polycentric governance for marine conservation in Palau. 
We evaluate the polycentricity of the PAN by asking who is initiating institutional change and why; how the change is legitimized with reference to ecological scale; and how the change redistributes rule-making authority and affects resource user autonomy. We define autonomy as the ability of marine resource users to devise their own institutions for the governance of marine resources without being challenged by non-local units (modified from Ostrom, 1990). Autonomy can foster (or not) the development of diverse, context-appropriate institutions, and as such is seen as a pivotal concept in understanding the emergence and endurance of a local CPR regime (Basurto, 2013; Ostrom, 2005; Schlager, 2002). In recognition that there are few, if any, examples of completely isolated social-ecological systems, we approach autonomy relationally. Accordingly, our analysis examines the ways in which marine resource users' autonomy changes over time through dynamic institutions-in-use.

\section{Methods}

The first author collected field data during three trips to Palau totaling four and a half months over the period 2010-2012. Data sources include 101 semi-structured interviews with 72 people (19 key informants were interviewed 2-4 times), observation of seven policy planning meetings, and documents related to protected area science and policy in Palau throughout the 1980s-2000s. Interviewees included two heterogeneous groups we refer to as resource users and PAN architects. These analytical groupings are not mutually exclusive; three individuals spoke at length from both perspectives and are thus included in both groups.

Interviews with 39 marine resource users from each of Palau's 16 states, included 13 out of the 16 state governors, other elected or appointed state officials, traditional leaders (chiefs herein), and volunteers on conservation committees. According to the Palau National Constitution (Article 1, Section 2, 1979), Palau's states hold "exclusive ownership" of the ocean and its resources from the land to 12 nautical miles seaward (Section 4 discusses the meaning of ownership). Most Palauan states are small communities comprised of a few hundred people from historically unified social and political units (Graham and Idechong, 1998). Nearly all households in Palau are involved in coastal fishing activities, so Palauan states may be understood as communities of resource owner/users (who we refer to as resource users herein) (FAO, 2009; Freidman and Golbuu, 2011). Interviews with resource users focused on the history of protected area designation and management in his/her state, interpretations of and experiences with the PAN, and decisions to enroll protected areas into the PAN.

Interviewees also included 36 PAN architects who conceptualized, developed, and communicated the PAN, including 10 current and former members of Palau's national government and 26 former and current NGO affiliates of The Nature Conservancy (TNC) and Palau Conservation Society. Interviews with PAN architects focused on drivers and rationales for the PAN, design of PAN institutions, and interpretations of PAN objectives, institutional processes, and participant roles. PAN architects are coded and cited as A1-A36, and resource users as R1-R39.

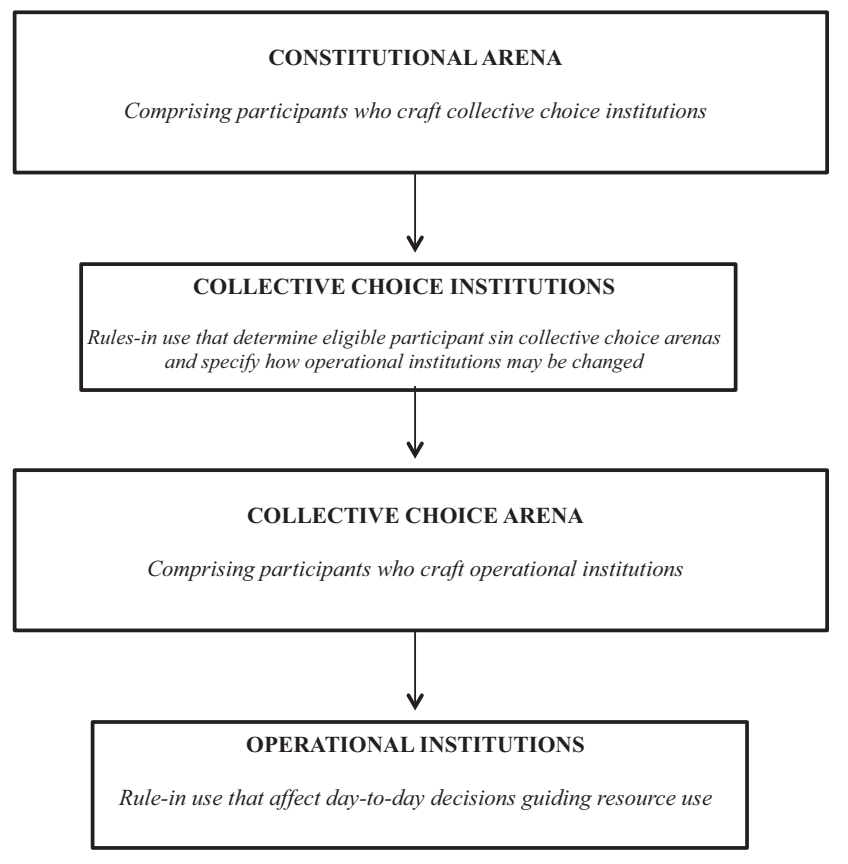

Fig. 1 - Levels of institutional analysis. Adapted from Ostrom, 2005.

Drawing from interviews, observations, and historical documents enabled us to triangulate data and undertake an ethnographically "thick" approach (Geertz, 1973, p. 3) to institutional analysis that recognizes embeddedness of actors and institutions within particular social, political, and environmental situations (McCay and Jentoft, 1998). Data collection and analysis were guided by constructivist grounded theory, whereby data collection and analysis take place simultaneously, with emergent theory guiding the collection effort (Charmaz, 2000). Analysis of institutional change is guided by four interlinked levels of institutions and action arenas: operational, collective choice, constitutional, and meta-constitutional (Ostrom, 2005). Operational institutions directly affect the biophysical world and are crafted in collective choice arenas. Collective choice institutions determine eligible participants in operational arenas and specify how operational institutions may be changed. Collective choice institutions are crafted in constitutional arenas, and so on (Fig. 1). We complement observations and institutional analysis with interpretive analysis that focuses on the situated meaning of institutions to different actors (Yanow, 1996).

\section{Pre-PAN polycentric marine governance (before 2003)}

Situated roughly $800 \mathrm{~km}$ east of the Philippines and $800 \mathrm{~km}$ north of Papua New Guinea, Palau is an archipelago comprising 586 small islands and an ocean territory of $616,029 \mathrm{~km}^{2}$ (Freidman and Golbuu, 2011). The total land area of the largest island is about $400 \mathrm{~km}^{2}$. Palau's population is around 20,000 and tourism is their main source of revenue. Foreign vessels dominate industrial offshore export fisheries while coastal marine fisheries mainly support local subsistence and 
commercial uses critical to domestic food supply (FAO, 2009; Freidman and Golbuu, 2011). Palau's marine environment has the most diverse coral reef fauna in Micronesia (Golbuu et al., 2007), and is part of Conservation International's PolynesiaMicronesia Biodiversity Hotspot, described as the "epicenter of the current global extinction crisis" (CI, 2012).

In pre-colonial Palau, customary marine tenure was vested in traditional leaders and kin groups (Ueki and Clayton, 1999). Customary marine tenure has been defined as "a situation in which particular groups of people [. . . have informal or formal rights to coastal areas and in which their historical rights to use and access marine resources are, in principle, exclusionary, transferable, and enforceable" (Aswani, 2005, p. 287). In Palau this included bul or harvesting moratoriums, as well as religiously motivated taboos, practices that had the effect if not the sole intent of sustainable use. Violators could be fined, banished, shamed, or killed (Johannes, 1978).

Official colonial administrations from Spain, Germany, Japan and the U.S. governed Palau beginning in 1885. Imported legal and economic systems under U.S. and Japan administrations deteriorated customary marine tenure, leading to de facto open access fisheries conditions and perceptible fisheries decline (Ueki and Clayton, 1999). Palau gained independence in 1994, but maintains a formal political association with the U.S. Today, Palau's federated government mirrors that of the U.S., comprising a national government with an executive branch, a bi-cameral congress, and judiciary as well as 16 state governments each ruled by a constitution, elected governor, and legislature. The national constitution delegates power to the states, including power to enact and enforce laws.

The national constitution is based on U.S. democratic ideals, but also seeks to invigorate custom by granting equal authority to statutory and traditional law, which is unwritten and based on titled elitism and highly decentralized decision-making (Graham and Idechong, 1998). All states incorporate traditional authorities in their governments to varying degrees, and the strongest customary political power in Palau is arguably at the state level (Graham and Idechong, 1998). Inconsistencies between dual democratic-egalitarian and customary systems are many, and underwrite ongoing power struggles among Palau's traditional and elected leaders and also between state and national governments, given the role of traditional leaders in state governments (Graham and Idechong, 1998).

These struggles extend to marine resources. As mentioned earlier, the Palau National Constitution delegates to states "exclusive ownership of all living and non-living resources, except highly migratory fish, from the land to twelve (12) nautical miles seaward from the traditional baselines" (Article I, Section 2). Traditional baselines represent ownership as recorded through oral histories and use patterns, though boundary conflicts have arisen as most states have not mapped or strictly defined these baselines (Matthews, 2007; Pulea, 1994). The national constitution also contradictorily grants congress the power to "regulate the ownership, exploration and exploitation of natural resources" (Article IX, Section 5.12). Throughout the 1990s, traditional leaders, state governments, and national government fought for control over marine resources (Graham and Idechong, 1998). The courts supported states' authority to enact and enforce regulations for marine resource use (Graham and Idechong,
1998), effectively translating the clause for states' "exclusive ownership" into full property rights of access and withdrawal, management, exclusion, and alienation (Schlager and Ostrom, 1992).

In institutional terms, resource users had a high level of autonomy and ultimate authority to make collective choice and operational rules regarding marine resources, with enabling collective choice rules-in-use that recognized and supported their property rights and governing authority. The only constraints on local autonomy in practice were national fisheries laws regulating exploitation of particular species and fishing methods (Palau National Code, Title 24, Chapter 13).

\subsection{Re-emergence of customary marine tenure as polycentric practice (1980s to early 2000s)}

Resource users started actively exercising their right to selfgovern their resources in the 1980s. By the mid 1990s and early 2000s almost every state was establishing controls on fishing through buls and legislated MPAs, often with involvement from TNC and the Palau Conservation Society, a local NGO that TNC helped form in 1994. We refer broadly to buls and MPAs as conservation area herein. Nearly all resource users interviewed cited perceived fisheries declines as the primary motivation for initiating harvest controls, though the resurgence of buls was arguably also an expression of the chiefs' desire to re-exert control over marine resources following independence (Graham and Idechong, 1998). By 2003, 13 states had established at least 26 conservation areas (Palau Conservation Society, unpublished data), and by 2007 all states had established at least one (Fig. 2). Ongoing disputes between some states over resource ownership and access has arguably limited cooperative marine governance across state boundaries (Matthews, 2007).

Collective choice rules provided rule-making authority for conservation areas to chiefs and state governments, and in some cases, management boards comprising a mix of traditional leaders, state government leaders, and other community members. In most states, collective choice rules-in-use also permitted NGO involvement in the initiation, design, and implementation of operational rules to varying degrees. Nine state governors said that the Palau Conservation Society and/or TNC were involved in the initial designation of conservation areas in their state (the other four governors interviewed did not know). However, the extent of NGO involvement varied from state to state and was limited by small NGO staffs during this period. Operational rules governing conservation areas vary, but most include rules for boundaries, monitoring, conflict resolution, and graduated sanctions ranging from shaming to fines and imprisonment. Operational appropriation rules include no-entry and no-take regimes, season and species specific rules, and/or sustainable use for subsistence and education.

In summary, high local autonomy led to polycentric regimes for conservation areas characterized by some informal nonlocal involvement, context-specific rule-making, and institutional diversity. As one interviewee summarized: "when you went to one state conservation site it had a different policy from another" (A11). Interviews with resource users revealed high awareness of and support for marine conservation areas, 


\section{Conservation Areas} Republic of Palau
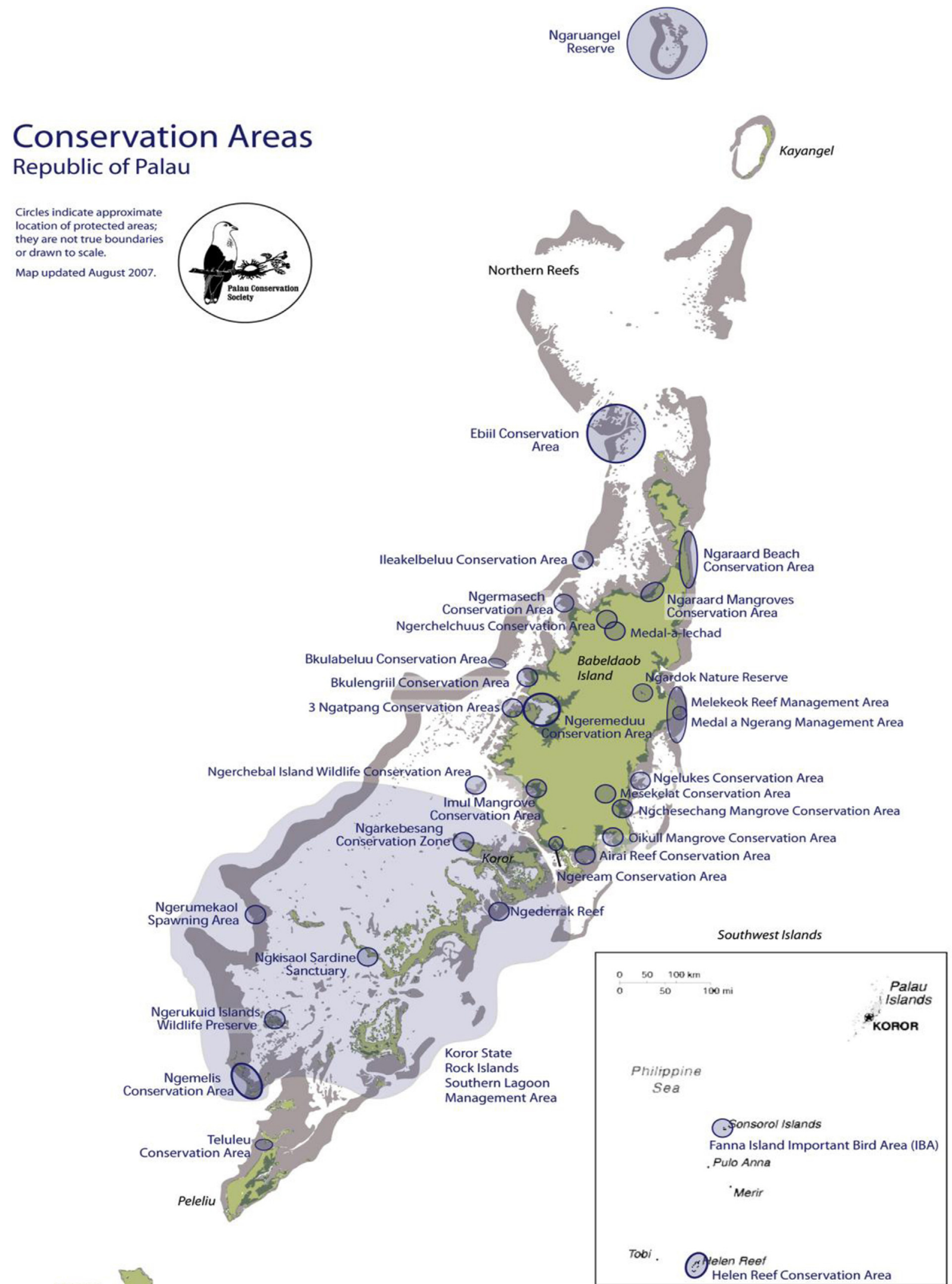

Conservation Area 1 Angaur

Fig. 2 - Conservation areas in Palau as of 2007, indicated by circles.

Copyright by Palau Conservation Society and Palau Automated Land Information Resource Services. Reprinted with permission. 
but most also reported some poaching, poorly marked boundaries, and insufficient funding for fully implementing rules. The primary source of state revenue for government operations is an annual grant from the national government; excluding the state of Koror, the average FY2011 allocation was US $\$ 237,000$, which left insufficient funds to manage conservation areas according to some interviewees.

\section{Nesting polycentric systems through PAN (beginning in 2003)}

\subsection{Initiation and legitimization of PAN: prioritizing ecological scale}

The initial PAN Act (2003) was primarily conceptualized and designed by about ten PAN architects, including Palauans and non-Palauans working for NGOs and Palau's national government. Resource users reported limited involvement in the initial stages of institutional development. The main motivation for developing a national, science-based protected area network was the conservation of marine biodiversity, which arguably required management of ecological and social-institutional processes across larger, spatial scales stretching across state boundaries. Coordination needs served as a justification for shifting some local control over conservation areas to centralized agencies through institutional reforms that nested local institutions for conservation areas within new national institutions. The maintenance of natural processes at ecologically relevant scales served to legitimize this shift.

PAN architects cited two main drivers for institutional change. The first was their heightened concern about marine biodiversity in Palau after a massive coral bleaching and mortality event in a particular ecosystem type in 1998 (see Golbuu et al., 2007). In anticipation of future threats from climate change and ocean acidification, PAN architects drew on resilience theory to conclude there was a mismatch between governance and the spatial scale of ecological processes considered relevant to conserving marine biodiversity. They reasoned that maintaining ecological connectivity, representation, and resilience required governing at larger spatial scales than individual state territories as was the current practice. This understanding justified expanding authority for national government to centrally coordinate the designation of conservation areas across Palau:

"if you leave it up to the communities they're always going to think about fisheries resources mainly and they're going to think only within their state. And that's why you needed the national government to be a partner, because the national government can look at the whole of Palau, and address issues such as biodiversity and other issues that the state can't think about, and connectivity. You know states cannot think about the ecosystem" (A3).

PAN architects recognized that resource users did not necessarily share their goal of biodiversity conservation and would be wary of increased national involvement given the historic politics of control over marine resources. They legitimized increased involvement of larger organizational units with scalar narratives articulating incontrovertible relationships among social-ecological processes, scale, and outcomes (Sievanen et al., 2013), such as in the following:

"Koror state or another State cannot protect its natural resources alone because our resources are connected and interdependent .... the National and State government should work together to identify the important or critical habitats or species to ensure their survival" (Senator Adalbert Eledui, Television advertisement).

The prioritization of ecological connectivity in justifications for institutional re-arrangement may be understood as a form of anti-politics (Ferguson, 1990) that naturalizes inherently political projects. In other words, the focus on natural scalar processes discursively skirts the reconfiguration of decision-making power necessary for PAN architects to accommodate a new set of national goals (biodiversity conservation).

A secondary motivation for the PAN was to report progress toward Palau's commitment to the Convention on Biological Diversity, which has produced global biodiversity targets since 2002 and makes funding available through the Global Environment Facility for national implementation. One PAN architect reported that the PAN was designed to facilitate documentation of national-level progress toward international obligations so as to attract international recognition and associated financial support.

\subsection{Changing positions of non-local actors}

PAN architects restructured the existing polycentric regime to facilitate a more active role for national government and NGOs, thereby centralizing some aspects of decision-making. Specifically, the dynamic sequence of formal PAN laws, amendments, and regulations adopted between 2003 and 2008 created new action arenas and institutions in collective choice and constitutional levels that cumulatively restructured the process for designing operational institutions for state-owned conservation areas. The approach allowed nonlocal actors to influence operational rules without overt persuasion or total control (see Li, 2007). The logic was thus:

"the structure had to be seen on the one hand by the states to be advantageous to them, in the sense that they could control everything ... [but] we had to make sure that at the national level it did deal with some of the national obligations and priorities, they would still have some degree of control over the broad things" (A34).

Under the PAN Act (2003), states may voluntarily nominate new and/or pre-existing marine and terrestrial conservation areas to the national network. Participating states must manage sites in consultation with the national Ministry of Resources and Development (hereafter, the Ministry), and would be eligible for technical assistance and financial support. The PAN Act (2003) directed the Ministry to promulgate PAN rules and regulations for the operationalization of the PAN. In 2004, the Ministry signed a memorandum of understanding with TNC to work together to do so. Through 
the memorandum of understanding, TNC also agreed to fund a range of supporting technical work within the network.

Together, the Ministry and TNC designed a complex system of institutions through the PAN regulation (2007) that spelled out roles and rule-making procedures for PAN site selection, criteria and guidelines for PAN site management plans (which states must develop in conjunction with the Ministry within 12 months of joining PAN), and a technical committee that would review and comment on management plans and develop standardized environmental monitoring protocols for PAN sites. The process was designed to influence resource user decisions about conservation area designation as well as management: "the role of the technical committee and this whole application process was to help ensure that the states sort of choose the right areas, or when they put their boundaries they put them in a way that makes sense ecologically" (A24).
By early 2008, no state had joined the PAN because (a) resource users feared losing ownership and governance authority in PAN sites, and (b) there was no discernable source of financial support (access to financial resources later proved to be a powerful incentive). The PAN law was amended in 2008 to more explicitly recognize state government ownership and governance of PAN sites, and scale back the control of national government and NGOs through the creation of a "management committee" that would grant resource users formal authority in future constitutional arenas where overall PAN rules, regulations, and systemwide management plan would be developed. The amendment also created a financial incentive for states to join the PAN, outlining plans to collect a \$15 "Green Fee" from each departing visitor to be distributed by a "PAN Fund Board" to resource users to develop and implement management plans

\section{Pre-PAN}

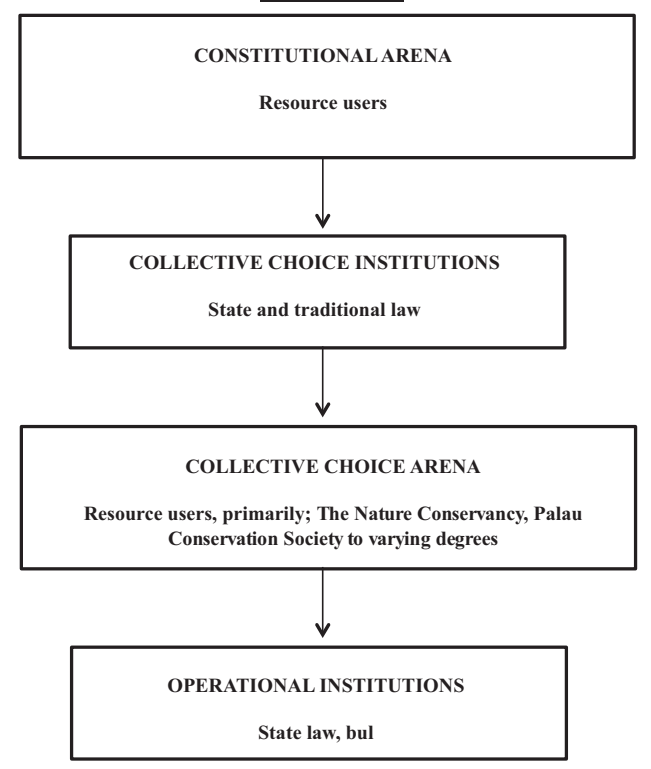

Post-PAN (applies to participating states only)

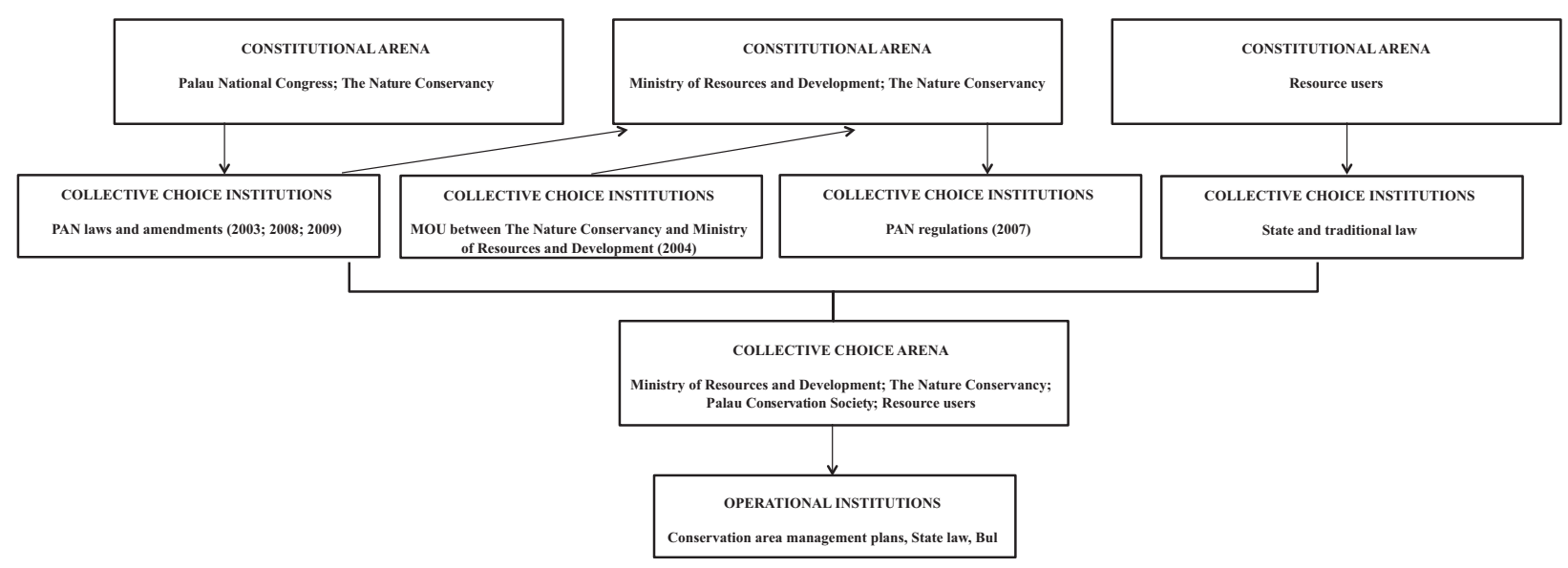

Fig. 3 - Institutional structure in-use for conservation area governance pre and post participation in PAN. Arrows denote directional connectivity between rule-makers in action arenas and institutions, and italics denote informal positions. Diagrams constitute simplifications of complex, highly dynamic governance systems also characterized by (unrepresented) informal institutional arrangements at all levels. 
in accordance with system-wide goals. Collection of the Green Fee began in 2009.

\subsection{Current nested polycentric structure for marine conservation area governance}

As of September 2011, much of the institutional infrastructure described in Section 5.2 was not yet functional, including the technical committee, the management committee, the PAN Fund board, and the system-wide management plan (see Fig. 3).

Although TNC conducted an ecoregional assessment in 2007 to inform the network design (Hinchley et al., 2007), it has not been used in formal application and review processes, given the absence of a technical committee. Lacking a functional scientific review process, NGOs stepped in to provide technical and scientific input by working with resource users to develop the management plans necessary to remain part of the PAN. This is a task that resource users felt they had limited capacity to do on their own:

"in order to become a member of the PAN, you have to have a state conservation management plan, in order to get the fund. That is what we need, we need the fund ... we have a natural idea of what we think is the nature of our place but those people from there [NGOs], like they have a science background, they have an environmental background to put it [the management plan] together" (R24).

Thus, by requiring a management plan, the PAN created a de facto leadership position in a collective choice arena for NGOs, which have the staff, funding, and technical means necessary to develop management plans. As organizers of the management planning process, NGOs introduce scientific knowledge and biodiversity conservation goals as integral elements of operational rules for conservation areas: "we try to start with the biodiversity as the targets and then ... you plan backwards ... the structure is already decided. ... you have to have a management group picked in a certain way, and they have to go through this certain routine." (A1).

Given that the PAN Fund board was not functional as of September 2011, \$1.4 million collected from departure fees remained in national government coffers and control. Eight states had confirmed PAN sites (all pre-existing conservation areas) and four had received $\$ 50,000$ each -a significant sum roughly equivalent to $20 \%$ of the average state's annual operating budget. Representatives from the remaining eight states said their state was moving forward to nominate at least one of their pre-existing conservation areas to the PAN. All resource users cited access to PAN funds as their main motivation for joining the PAN, a powerful incentive given that a majority of resource users interviewed expressed concerns about participating. As one person summarized:

"these guys from national government level and PCS [Palau Conservation Society] are going after [states]- hey guys, would you like to be registered or not? We've been waiting for you! Come on, there's money now! See, the [resource users'] perception is different [now] because at the beginning [there was] no money... now when you say
PAN, people think about Green Fee... And that's maybe contribute to $95 \%$ of the reason why they now want to [be a] member of this" (R39).

\subsection{Resource user autonomy as a measure of polycentricity}

Institutional analysis reveals the form of a given governance system: the participants, their relative positions, and associated rule-making authority. Our interest in autonomy, however, concerns the relationship between the form of a nested system and its functional polycentricism. Here we interrogate this relationship by exploring the ability of resource users to devise rules affecting the governance of PAN sites without being challenged by non-local actors. This section complements institutional analysis with an examination of how resource users perceive institutional change and their current and potential ability (not only authority) to act within the new regime.

All resource users interviewed said that states would maintain ownership of PAN sites. However, when asked about how the PAN has or would affect their control over decisionmaking, 18 felt that it would be unchanged, 5 said that control would be shared, 13 felt that it would greatly curtailed, and 3 were unsure. The 18 resource users who experienced and/or predicted retention of autonomy acknowledged the institutional changes cited above, but interpreted them as empowering. The logic of this group was generally: "I think [states] will just be able to implement what they wanted to do all along but didn't have the resources to do" (R33).

Those who anticipated or experienced loss of autonomy felt that the PAN increased rule-making authority of non-local actors; prioritized science and written law over local knowledge and traditional law; and increased their financial dependence. For example, one interviewee reported that the involvement of NGOs and national government in marine conservation area governance: "has significantly increased by the way they advise, and the
way activities have been carried out on the ground...when
you come to community and talk about hard science, stats
and data, you're stuffing them back in a hole. They don't
see what you're talking about, they don't see their way
out...So for example, our communities basically under-
stand that the resources, they are the owner. But how do
they manage it? They felt that they've lost sight, lost their
resources. They don't have a much say over it any longer"
(R35).

Others focused on the complexity and permanence of legally designating PAN sites, which could limit their ability to design and change conservation area rules in what they referred to as a practical, "Palauan" way:

"But whereas PAN, it's going to depend on some writing that takes a whole big process to reverse it. It's not as reversible as bul.... if PAN takes over, then maybe we can't do anything like we could if a bul or just a state law that conserves a place. . it doesn't make sense that PAN has to come in and put it in writing" (R38). 
Finally, others in this group feared the financial dependence enacted through the PAN, as expressed thus:

"once you're hooked to the strong hand of the money that they're gonna to give you, it's gonna be very hard to bite that hand. Who will bite the hand that's feeding them? And to me, that's our worry. That we will become reliant on the PAN fund and at some point they might say 'oh, well but we want you guys to do this.' And we will say 'no, that's not what our community wants.' [Then they will say] ok, 'then the funding stops.' We don't want to get to that stage but we're fully aware of that" (R37).

Many in this group used the dissociative language give or donate to describe the sale of their conservation area to outsiders through the PAN, i.e., "Now all the governors of all the states fighting to get the $\$ 50,000$ and give their land for the PAN. They say give us some money and we give you PAN site?" (R23).

Divergent interpretations of how the PAN has and will affect resource users' autonomy in governing conservation areas have led to divisive conflict in one state. In 2010, 50 people from Hatohobei state (roughly $25 \%$ ) signed a petition to remove their conservation area from the PAN. While petitioners were concerned about resource user autonomy, others felt those concerns were not justified:

"One of the arguments that came up was that the PAN is run by outsiders, not from Tobi, and if they want to make changes or make rules that will affect Helen Reef they can do so, which is not true" (R28).

The conflict in Hatohobei reflects the politics inherent in nested polycentric regimes as diverse actors negotiate changing roles both within and across action arenas controlling various aspects of decision-making.

At this stage, our interpretive institutional analysis suggests that the PAN represents movement on a continuum of polycentricity toward centralization and institutional homogenization. PAN architects control the financial resources that have motivated resource users to nominate areas to the PAN. As part of the PAN, resource users are beholden to new, deeper level rules set by PAN architects that reshape the process and objectives of institutional design. In particular, the requirement to have a conservation area management plan has made resource users dependent on NGOs that have the procedural and technical knowledge to produce one. As leaders in collective choice arenas, NGOs facilitate the design of management plans that make local conservation practices and progress legible (Scott, 1998) to those tasked with documenting progress toward national and international biodiversity agendas (i.e., through written documents, management budgets, paid enforcement staff, etc.). However, resource users still have ultimate ownership and rule-making authority in PAN sites as they may withdraw from the PAN should they choose to do so.

Finally, while our focus is on the social dimensions the PAN, it is important to highlight that the institutional changes described above have not yet led to significant reform in conservation area boundaries or placement. As Agardy (2005, p. 245) has argued,
"Identification of existing protected areas and tying them together into a regional initiative does not magically create large-scale conservation. [...] Since individual MPAs were historically established opportunistically rather than strategically, functional networks will require the creation of new MPAs to fill remaining gaps, even in areas where MPAs are common."

At the time of research, the PAN only included pre-existing conservation areas. Thus, the network has yet to advance large-scale conservation through enhanced ecological connectivity. To this point, tensions are also emerging among PAN architects about the foregrounding of ecological scale in the PAN, and associated roles for science, and national and NGO actors. Some envision a greater role for non-local actors and science through more strategic use of their control over PAN funds to influence the placement of PAN sites:

"They can still do their fisheries thing but if PAN said we want PAN site to be resilient network then you know that can happen. If PAN said we want site now that's going to be in the atmosphere then states would designate their atmosphere right now, they want the money now. I think it just. . PAN needs to be active" (A30).

Other key PAN architects envision a less influential role for non-local actors, understanding PAN foremost as a mechanism for supporting and empowering resource users:

"What I disagree with is that we should impose the ecoregional assessment on our communities and say only these sites.... if it's science driven it won't last, it won't be sustainable. The scientists aren't going to manage these areas" (A25).

\section{Discussion and conclusions}

If the success of a polycentric system is dependent in part on the ability of resource users to craft and adjust their own rules over time (Andersson and Ostrom, 2008), there is a need for critical reflection on how new configurations of actors, interests, and institutions in nested regimes for larger CPRs affect the autonomy of resource users-or, the degree to which the nested system is polycentric. Toward this end, we demonstrate the potential for constructive dialog between institutional theorists and critical human geographers. We do not argue for complete theoretical integration, but rather, for the analytical utility of engaging key elements from each perspective.

We engage scalar politics to contribute a critical perspective on the drivers and legitimization of nested, polycentric regimes for large-scale marine governance in Palau (see also Lee (2013) on the importance of legitimacy in the functionality of polycentric regimes). An institutional analysis informed by scalar politics draws attention to the actors and agendas that drive institutional rearrangement in accordance with particular governance goals that are not necessarily shared. Through the PAN in Palau, actors who held no property rights over inshore marine resources rescaled a relatively decentralized, polycentric marine governance regime primarily because they 
felt that the existing regime did not and could not adequately conserve marine biodiversity. They legitimized governance at a larger spatial scale and higher jurisdictional level than individual state territories through an ecological connectivity argument, an expression of scalar politics that is reflective and productive of struggles for control over the goals and processes of governance (Swyngedouw, 2000; Sievanen et al., 2013).

Critical human geographers may also find useful analytical tools in Bloomington institutionalism. We engage institutional analysis underpinning ideas about polycentricity to systematically identify the changes in operational, collective choice, and constitutional rules and arenas that both reflect and serve those scalar projects and associated priorities. Organizing analysis around levels of institutions enabled a more systematic, nuanced assessment of the control actors gain or lose over specific parts of decision-making processes. Finally, we also draw from polycentricity to identify autonomy and institutional diversity as policy-relevant metrics by which to assess how scalar politics affects the outcomes of a governance regime.

Our interdisciplinary analysis suggests that the prioritization of ecological scale in institutional reform resulted in more nested but less polycentric institutional arrangements governing the network in Palau. In a highly polycentric system where resource users can modify rules, CPR institutions are more likely to be tailored to local circumstances (Ostrom, 1990). Engendering feelings of lost local autonomy and devalued knowledge systems risks crowding out conditions that may contribute to enduring, diverse institutions that could yield intended outcomes - whether fisheries or biodiversity or both, in the case of Palau. While we do not critique the general scientific argument for organizing marine biodiversity conservation at larger scales, our results are cautionary, highlighting potential tradeoffs that may accompany the prioritization of ecological scale as a guide for institutional reform. These include potential tradeoffs between governance goals, tradeoffs between institutional nestedness and polycentricity, and, ultimately, tradeoffs between biological and institutional diversity.

It is not yet clear how the degree of decreased autonomy in Palau will affect institutional innovation and diversity. In the small island of Palau, national government and NGOs also include resource users; therefore, so-called "non-local" influence is exercised by people who hold a relatively high degree of contextual social and environmental knowledge. Moreover, "processes of rescaling do not entail the simple replacement of one scalar configuration with another fully formed one" (Sievanen et al., 2013, p. 213); they are dynamic, continual processes of social negotiation. Continued research is necessary to track how the PAN will affect institutional innovation and diversity considered necessary to arrive at rules that are well matched to social and ecological contexts.

We identify a series of inter-related questions for future research relevant to marine governance in Palau, the design of MPA networks, and interdisciplinary scholarship on the governance of larger scale CPRs. How does increased nestedness and decreased resource user autonomy in Palau affect institutional innovation and diversity? Are institutional monocultures the likely result of scaling up MPA governance? Does increased nestedness necessarily decrease resource users' autonomy in polycentric systems? If so, is there a tension between the argument for jurisdictional nesting as a design principle for larger CPRs and the argument for resource user autonomy in polycentric systems? In Palau and more generally, there is a need for long-term institutional research on how the dynamic distribution of control in nested, polycentric regimes links to particular social and ecological outcomes.

In conclusion, interdisciplinary perspectives from institutional analysis and critical human geography can reveal how multi-level regimes change over time as people experiment, learn, and also struggle for control of the process. In research and policy agendas it will be important to consider how larger organizations may support as well as limit institutional innovation and autonomy while endeavoring to govern at ecologically-relevant spatial scales, given that "protecting institutional diversity related to how diverse peoples cope with CPRs may be as important for our long run survival as the protection of biological diversity" (Ostrom, 1999, p. 282).

\section{Acknowledgements}

Funding for this research came from a Doctoral Dissertation Research Improvement Grant from the National Science Foundation, Geography and Spatial Sciences Program (award no: 1130675). The authors are grateful to informants, whose generosity in sharing their time, experiences, and insights made this research possible. The authors also thank Kenji Dengokl and Dirremeang Oiterong for research assistance, and Abigail Bennett, Lisa Campbell, Catherine Corson, Luke Fairbanks, Tarita Holm, Kimberly R. Marion Suiseeya, and two reviewers for helpful feedback.

\section{R E F E R E N C E S}

Adger, W., Brown, K., Tompkins, E.L., 2005. The political economy of cross-scale networks in resource comanagement. Ecology and Society 10

Airamé, S., Dugan, J., Lafferty, K., 2003. Applying ecological criteria to marine reserve design: a case study from the California Channel Islands. Ecological Applications 13, S170-S184.

Agardy, T., 2005. Global marine conservation policy versus sitelevel implementation: the mismatch of scale and its implications. Marine Ecology Progress Series 300, 242-296.

Aligica, P., Boettke, P., 2011. The two social philosophies of Ostroms' Institutionalism. Policy Studies Journal 39, 29-49.

Andersson, K.P., Ostrom, E., 2008. Analyzing decentralized resource regimes from a polycentric perspective. Policy Sciences 41, 71-93.

Araral, E., 2013a. Ostrom, Hardin and the commons: a critical appreciation and a revisionist view. Environmental Science and Policy (in this issue).

Araral, E., 2013b. Does geography matter to institutional choice? A comparative study of ancient commons. Geoforum 44, 224-231.

Armitage, D., 2008. Governance and the commons in a multilevel world. International Journal of the Commons 2, 7-32.

Aswani, S., 2005. Customary sea tenure in oceania as a case of rights-based fishery management: does it work??. Reviews in Fish Biology and Fisheries 15, 285-307. 
Basurto, X., 2013. Linking multi-level governance to local common-pool resource theory using fuzzy set qualitative comparative analysis: insights from twenty years of biodiversity conservation in Costa Rica. Global Environmental Change 23, 573-587.

Botsford, L., Micheli, F., Hastings, A., 2003. Principles for the design of marine reserves. Ecological Applications 13, 25-31.

Brewer, J., 2010. Polycentrism and flux in spatialized management: evidence from Maine's lobster (Homarus Americanus) fishery. Bulletin of Marine Science 86, 287-302.

Brown, C., Purcell, M., 2005. There's nothing inherent about scale: political ecology, the local trap, and the politics of development in the Brazilian Amazon. Geoforum 36, 607-624.

Campbell, L.M., 2007. Local conservation practice and global discourse: a political ecology of sea turtle conservation. Annals of the Association of American Geographers 97, 313-334.

Campbell, L.M., Godfrey, M.H., 2010. Geo-political genetics: claiming the commons through species mapping. Geoforum 41, 897-907.

Charmaz, K., 2000. Grounded theory: objectivist and constructivist methods. In: Denzin, N., Lincoln, Y. (Eds.), Handbook of Qualitative Research. Sage, London, pp. 509535.

CI, 2012. Polynesia-Micronesia [WWW Document]. http:// www.conservation.org/where/priority_areas/hotspots/asiapacific/Polynesia-Micronesia/Pages/default.aspx (accessed 12.12.12).

Clement, F., 2009. Analysing decentralised natural resource governance: proposition for a politicised institutional analysis and development framework. Policy Sciences 43, 129-156.

Cohen, A., 2012. Rescaling environmental governance: watersheds as boundary objects at the intersection of science, neoliberalism, and participation. Environment and Planning A 44, 2207-2224.

FAO, 2009. National fishery sector overview: Palau.

Ferguson, J., 1990. The Anti-politics Machine: Development, Depoliticization, and Bureacratic Power in Lesotho. Cambridge University Press, New York.

Freidman, K., Golbuu, Y., 2011. Palau. In: Marine Protected Areas: Country Case Studies on Policy, Governance and Institutional Issues. FAO Fisheries and Aquaculture Technical Paper. 51-68.

Gaines, S.D., White, C., Carr, M.H., Palumbi, S.R., 2010. Designing marine reserve networks for both conservation and fisheries management. Proceedings of the National Academy of Sciences 107, 18286-18293.

Geertz, C., 1973. The Interpretation of Cultures. Basic Books, New York.

Giordano, M., 2003. The geography of the commons: the role of scale and space. Annals of the Association of American Geographers 93, 365-375.

Golbuu, Y., Victor, S., Penland, L., Idip, D., Emaurois, C., Okaji, K., Yukihira, H., Iwase, a., Woesik, R., 2007. Palau's coral reefs show differential habitat recovery following the 1998bleaching event. Coral Reefs 26, 319-332.

Graham, T., Idechong, N., 1998. Reconciling customary and constitutional law: managing marine resources in Palau, Micronesia. Ocean \& Coastal Management 40, 143-164.

Gray, N.J., 2010. Sea change: Exploring the international effort to promote marine protected areas. Conservation and Society 8, 331-338.

Grilo, C., 2011. Institutional interplay in networks of marine protected areas with community-based management. Coastal Management 39, 440-458.

Gruby R.Campbell L., Scalar politics and the region: strategies for transcending Pacific Island smallness on a global environmental governance stage. Environment and Planning A, (in press)

Heikkila, T., Schlager, E., Davis, M.W., 2011. The role of crossscale institutional linkages in common pool resource management: assessing interstate river compacts. Policy Studies Journal 39, 121-145.

Hinchley, D., Lipsett-Moore, G., Sheppard, S., Sengebau, F.U., Verheij, E., Austin, S., 2007. Biodiversity Planning for Palau's Protected Areas Network: An EcoregionalAssessment. , TNC Pacific Island Countries Report No. 1/07.

Johannes, R., 1978. Traditional marine conservation methods in oceania and their demise. Annual Review of Ecology and Systematics 9, 349-364.

Johnson, C., 2004. Uncommon ground: the poverty of historyin common property discourse. Development and change 35, 407-433.

Lee, M.K., 2013. The potential role of boundary organizations in the climate regime. Environmental Science and Policy (in this issue).

Lejano, R.P., 2006. Frameworks for Policy Analysis. Routledge, New York.

Li, T.M., 2007. The Will to Improve. Duke University Press, Durham.

Lowry, G.K., White, A.T., Christie, P., 2009. Scaling up to networks of marine protected areas in the philippines: biophysical, legal, Institutional, and Social Considerations. Coastal Management 37, 274-290.

MacKinnon, D., 2011. Reconstructing scale: towards a new scalar politics. Progress in Human Geography 35, 21-36.

Mansbridge, J., 2013. The role of the state in governing the commons. Environmental Science and Policy (this issue).

Marshall, G., 2008. Nesting, subsidiarity, and community-based environmental governance beyond the local level. International Journal of the Commons 2, 75-97.

Matthews, E., 2007. Community-Based and Collaborative Management of Coral Reefs and Coastal Resources in Palau. University of Rhode Island, Doctoral Dissertation.

McCarthy, J., 2005. Scale, sovereignty, and strategy in environmental governance. Antipode 37, 731-753.

Mccay, B.J., Jentoft, S., 1998. Market or community failure? Critical perspectives on common property research. Human Organization 57, 21-29.

Moffitt, E.A., White, J.W., Botsford, L.W., 2011. The utility and limitations of size and spacing guidelines for designing marine protected area (MPA) networks. Biological Conservation 144, 306-318.

Mosse, D., 1997. The symbolic making of a common property resource: history, ecology and locality in a tank-irrigated landscape in South India. Development and Change 28, 467-504.

Norman, E., Bakker, K., 2009. Transgressing scales: water governance across the the Canada-U S. borderland. Annals of the Association of American Geographers 99, 99-117.

Ostrom, E., 1990. Governing the Commons. Cambridge University Press, New York.

Ostrom, E., 1999. Revisiting the commons: local lessons, global challenges. Science 284, 278-282.

Ostrom, E., 2005. Understanding Institutional Diversity. Princeton University Press, Princeton.

Ostrom, E., 2009. A general framework for analyzing sustainability of social-ecological systems. Science 325, 419-422.

Ostrom, E., 2010. Polycentric systems for coping with collective action and global environmental change. Global Environmental Change 20, 550-557.

Ostrom, E., 2012. Why do we need to protect institutional diversity??. European Political Science 11, 128-147. 
Ostrom, V., Tiebout, C., Warren, R., 1961. The organization of government in metropolitan areas: a theoretical inquiry. The American Political Science Review 55, 831-842.

Poteete, A., 2012. Levels, scales, linkages, and other multiples affecting natural resources. International Journal of the Commons 6, 134-150.

Pulea, M., 1994. Environmental Legislation Review: Republic of Palau. South Pacific Regional Environment Programme, Apia.

Roberts, C., Branch, G., Bustamante, R., Castilla, J.C., Dugan, J., Halpern, B., Lafferty, K., Leslie, H., Lubchenco, J., McArdle, D. Ruckelshaus, M., Warner, R., 2003. Application of ecological criteria in selecting marine reserves and developing reserve networks. Ecological Applications 13, 215-228.

Schlager, E., 2002. Rationality, cooperation, and common pool resources. American Behavioral Scientist 45, 801-819.

Schlager, E., Ostrom, E., 1992. Property-rights regimes and natural resources: a conceptual analysis. Land Economics 68, 249-262.
Scott, J.C., 1998. Seeing Like a State. Yale University Press, New Haven.

Sievanen, L., Gruby, R.L., Campbell, L.M., 2013. Fixing marine governance in Fiji? The new scalar narrative of ecosystembased management. Global Environmental Change 23, 206-216.

Sneddon, C., 2003. Reconfiguring scale and power: the KhongChi-Mun project in northeast Thailand. Environment and Planning A 35, 2229-2250.

Swyngedouw, E., 2000. Authoritarian governance, power, and the politics of rescaling. Environment and Planning D 18, 63-76.

Swyngedouw, E., Heynen, N.C., 2003. Urban political ecology, justice and the politics of scale. Antipode 35, 898-918.

Ueki, M., Clayton, S.M., 1999. Eco-consciousness in traditional Palauan society. Asian Geographer 18, 47-66.

Yanow, D., 1996. How Does A Policy Mean? Georgetown University Press, Washington, D.C..

Young, O., 2006. Vertical interplay among scale-dependent environmental and resource regimes. Ecology and Society 11 . 